\title{
Well-being and Emotional Connectedness during the COVID-19 Pandemic
}

\author{
Subhash C Parija ${ }^{1}$, B Sivaprakash ${ }^{2}$ \\ Pondicherry Journal of Nursing (2020): 10.5005/jp-journals-10084-12154
}

Outbreaks of infectious diseases such as the coronavirus disease 2019 (COVID-19) can be quite stressful. In view of the profound impact that COVID-19 has on our state of mind, several authorities such as the World Health Organization (Geneva), Centers for Disease Control and Prevention (Atlanta), and the Ministry of Health and Family Welfare, Government of India, have published several helpful, exhaustive, and pragmatic guidelines for the benefit of the public. ${ }^{1,2} \mathrm{~A}$ strong partnership between media professionals and healthcare personnel will serve to disseminate such vital information to the masses during these hard times. Learning about these psychological support strategies is additionally important considering the deep connection between our mental and physical health. The powerful and complex mind-brain-body interface can be conceptualized as a backdrop to this epic war between man and virus.

It has been observed that humans may experience overwhelming fear and anxiety about a disease such as COVID-19. It is understandable that such global outbreaks can induce negative emotions. Lockdown circumstances and physical isolation can impose additional demands on our mental resources. ${ }^{3} \mathrm{~A}$ recent paper published in the Lancet, a leading international journal, states that "the psychological impact of quarantine is wide ranging, substantial, and can be long lasting". ${ }^{4}$ However, it needs to be borne in mind that healthy psychological coping strategies can actually help us emerge stronger. We need to harness the immense capacity for endurance that often lies dormant within our minds.

Stress during such pandemics can include excessive worry/ fear about our own personal health and the health of our near and dear ones. ${ }^{5}$ This is understandable, given these circumstances. We might experience some changes in the pattern of our sleep or our appetite and food intake. We might have difficulty concentrating too. Those of us who have preexisting chronic health problems and mental health conditions might notice a worsening situation. ${ }^{6-8}$ Some people might feel an increased craving for alcohol, tobacco, or other drugs.

Knowledge about accepted ways to cope with stress is now largely in the public domain and is mostly derived from common sense. Any healthy strategy that helps us cope with psychological stress will definitely be useful during this pandemic too. Experts have emphasized upon the need to take frequent breaks from watching, reading, or listening to news about COVID-19. ${ }^{9}$ This implies breaks from reading social media posts too. Being exposed to news about the pandemic throughout the day can be detrimental to our psychological well-being. Keeping abreast of the news is important but should not be carried to an extreme.

Scientific evidence supports the health benefits of yoga, meditation, and music. It stands to reason that one could draw upon these popular mind-body approaches to boost mental and physical resilience during such outbreaks of infectious diseases.

\begin{abstract}
${ }^{1}$ Sri Balaji Vidyapeeth, Puducherry, India
${ }^{2}$ Department of Psychiatry, Mahatma Gandhi Medical College and Research Institute, Sri Balaji Vidyapeeth, Puducherry, India

Corresponding Author: B Sivaprakash, Department of Psychiatry, Mahatma Gandhi Medical College and Research Institute, Sri Balaji Vidyapeeth, Puducherry, India, Phone: +91 9894021098, e-mail: prakashb1685@gmail.com

How to cite this article: Parija SC, Sivaprakash B. Well-being and Emotional Connectedness during the COVID-19 Pandemic. Pon J Nurs 2020;13(2):23-24.
\end{abstract}

Source of support: Nil

Conflict of interest: None

Additionally, deep breathing is a good way to relax and manage stress. The positive effects of physical exercise on mental health and the immune system are well documented. ${ }^{10,11}$ An indoor hobby is also a good way to handle stress and isolation during the COVID-19 outbreak. In the context of stress management, it is pertinent to emphasize that sleep has a vital restorative function; the average adult requires 7-9 hours of sound sleep to be able to handle stress well. ${ }^{12}$ At this juncture, one must not forget that addictive substances such as alcohol, tobacco, and drugs are not solutions. Consultation with a mental health professional is recommended for the safe management of these addictions during this pandemic.

Social distancing has been highlighted as a measure to practice, ensuring safe physical distancing between two persons to avoid exposure to the pathogen, during this pandemic. However, the concept of "safe physical distancing" is often misconstrued as "social isolation" wherein one cuts off all types of communication with people. ${ }^{13}$ This consequently may lead to loneliness, which can be a precursor to negative emotional states, poor self-regulation, addictive behaviors, depression, and suicide. "Emotional connecting" will act as the bridge over the gap created by social distancing. "Emotional connectedness" brings the people we love before us-either in person or through the virtual media-and is characterized by the exchange of pleasantries, expression of care and affection, providing emotional support, and sharing positivity. This is the need of the hour in this tough period.

Last but not the least, it is noteworthy that several governmental and private agencies in India have recently established special helplines that provide psychological support during these difficult circumstances. All these online psychological support services are believed to provide a safe channel to express psychological distress and receive professional advice with regard to stress management and coping strategies, especially in connection with the ongoing coronavirus pandemic. The student community, which faces special challenges during this lockdown, is also encouraged to reap the benefits of the services offered by these helplines. 
In conclusion, "physical distancing" can be offset, to a large extent, by "emotional connecting." Let us capitalize on this opportunity to reach out to family members and friends. A deep sense of positivity can be gained by using all available channels of electronic communication to revive and nurture precious relationships that have been compromised by frenetic office schedules. Confiding in the people we trust can be therapeutic.

\section{References}

1. CDC. Coronavirus Disease 2019 (COVID-19) [Internet]. Centers for Disease Control and Prevention. 2020 [cited 2020 Jun 15]. Available from: https://www.cdc.gov/coronavirus/2019-ncov/prevent-gettingsick/social-distancing.html.

2. World Health Organization. Advice for public [Internet]. 2020 [cited 2020 Jun 15]. Available from: https://www.who.int/emergencies/ diseases/novel-coronavirus-2019/advice-for-public.

3. World Health Organization. Mental health and COVID-19 [Internet]. 2020 [cited 2020 Jun 15]. Available from: https://www.who.int/teams/ mental-health-and-substance-use/covid-19.

4. Brooks SK, Webster RK, Smith LE, Woodland L, Wessely S, Greenberg $\mathrm{N}$, et al. The psychological impact of quarantine and how to reduce it: rapid review of the evidence. Lancet 2020;395(10227):912-920. DOI: 10.1016/S0140-6736(20)30460-8.

5. Lima CKT, de Medeiros Carvalho PM, de Lima IAAS, de Nunes JVAO, Saraiva JS, de Souza Rl, et al. The emotional impact of coronavirus 2019-nCoV (new coronavirus disease). Psychiatry Res 2020;287:112915. DOI: 10.1016/j.psychres.2020.112915.
6. Fonseca L, Diniz E, Mendonça G, Malinowski F, Mari J, Gadelha A Schizophrenia and COVID-19: risks and recommendations. Braz J Psychiatry 2020;42(3):236-238. DOI: 10.1590/1516-4446-20200010.

7. Kola L. Global mental health and COVID-19. Lancet 2020. . Available from: https://www.thelancet.com/journals/lanpsy/article/PIIS22150366(20)30235-2/abstract.

8. Chatterjee SS, Barikar CM, Mukherjee A. Impact of COVID-19 pandemic on pre-existing mental health problems. Asian J Psychiatr 2020;51:102071. DOI: 10.1016/j.ajp.2020.102071.

9. Depoux A, Martin S, Karafillakis E, Preet R, Wilder-Smith A, Larson H. The pandemic of social media panic travels faster than the COVID19 outbreak. J Travel Med 2020;27(3):taaa031. DOI: 10.1093/jtm/ taaa031Available from: https://www.ncbi.nlm.nih.gov/pmc/articles/ PMC7107516/.

10. Deslandes A, Moraes $H$, Ferreira $C$, Veiga $H$, Silveira $H$, Mouta $\mathrm{R}$, et al. Exercise and mental health: many reasons to move. Neuropsychobiology 2009;59(4):191-198. DOI: 10.1159/ 000223730.

11. Mikkelsen K, Stojanovska L, Polenakovic M, Bosevski M, Apostolopoulos V. Exercise and mental health. Maturitas 2017;106: 48-56. DOI: 10.1016/j.maturitas.2017.09.003.

12. Goldstein AN, Walker MP. The role of sleep in emotional brain function. Annu Rev Clin Psychol 2014;10:679-708. DOI: 10.1146/ annurev-clinpsy-032813-153716.

13. Abel T, McQueen D. The COVID-19 pandemic calls for spatial distancing and social closeness: not for social distancing!. Int J Public Health 2020;65(3):231. DOI: 10.1007/s00038-020-01366-7. 